\section{Macrodystrophia lipomatosa of bilateral hands and the left upper limb with syndactyly}

SukJoon Oh

Department of Burns and Reconstructive Surgery, Bestian Seoul Hospital, Seoul, Korea

Correspondence: Suk Joon Oh

Department of Burns and Reconstructive Surgery, Bestian Seoul Hospital, 429 Dogok-ro, Gangnam-gu, Seoul 06208, Korea

Tel: +82-70-7609-9321, Fax: +82-70-7005-4233

E-mail:sjoh46@nate.com

Received: 12 Mar 2019 • Revised: 24 Apr 2019 • Accepted: 4 May 2019 pISSN: 2234-6163・ elSSN: 2234-6171

https://doi.org/10.5999/aps.2019.00339

Arch Plast Surg 2019:46:392-393

Copyright (C) 2019 The Korean Society of Plastic and Reconstructive Surgeons

This is an Open Access article distributed under the terms of the Creative Commons

Attribution Non-Commercial License (http://creativecommons.org/licenses/by-nc/4.0/) which permits unrestricted non-commercial use, distribution, and reproduction in any medium, provided the original work is properly cited.

A 15-year-old girl from Myanmar presented to our department, and large growing malformations of the left upper limb and the dorsal (Fig. 1) and volar (Fig. 2) aspects of both hands were noted. These deformities had been present since birth, and they had progressively become more pronounced. The metacarpal and phalangeal bones of the right thumb, index, middle fingers and all the left fingers appeared hypertrophic on an X-ray examination. Computed tomography (CT) (Fig. 3) and magnetic resonance imaging (MRI) showed diffusely inflated fat tissue spreading through the lesions without encapsulation. Macrodystrophia lipomatosa (MDL) was diagnosed based on the patient's clinical presentation and CT a massive mass i hands and left upper limb. Her body posture was tilted by the asymmetrical weight of both upper limbs. and MRI findings. The bilateral distribution of MDL, including the entire upper extremity, was extremely rare $[1,2]$. She underwent three operations. The first operation consisted of ray amputation of the right index and middle finger (790 g) and opponensplasty using the third flexor digitorum longus tendon. The second operation consisted of resection of the left axillary mass $(370 \mathrm{~g})$ and liposuction of the left chest wall and upper arm $(250 \mathrm{~mL})$. The third operation

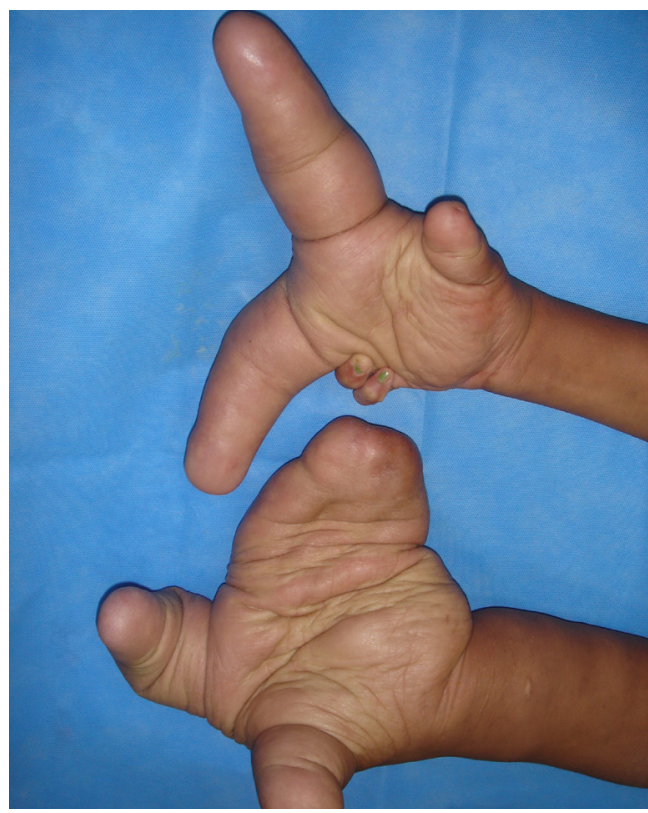

Fig. 2.

This photo shows the palms of the right hand and left hand with syndactyly affecting the fingers.

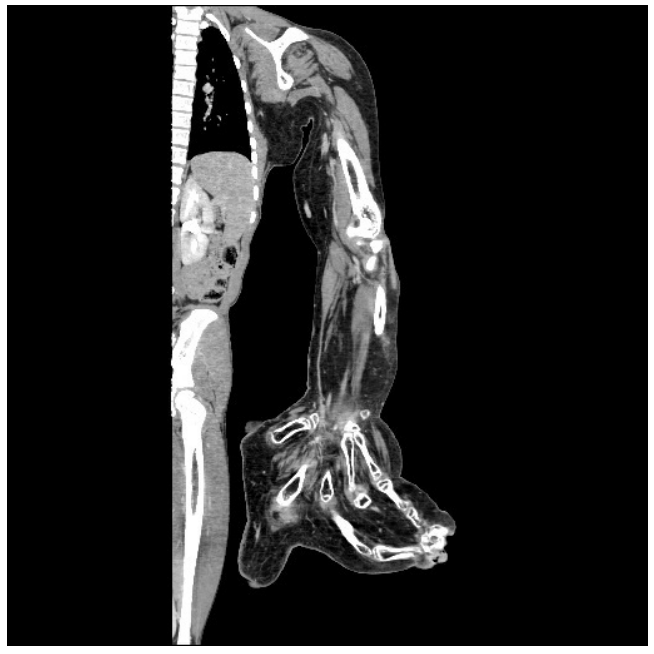

Fig. 3.

Computed tomography finding in the left upper limb shows enlarged adipose tissue spreading through the lesion without encapsulation. 
consisted of resection of lipomatous tissue in the left forearm with ray amputation of the left syndactylized middle, ring, and little fingers $(900 \mathrm{~g})$.

Histopathology showed mature adipose tissue scattered within fine, mesh-like fibrous tissue. The wounds healed uneventfully. After surgery, she showed improved grasp in the right hand and reduced deformities of both hands and the left axilla (Fig. 4).

The patient was no longer able to perform fine motor actions.

\section{Notes}

\section{Conflict of interest}

No potential conflict of interest relevant to this article was reported.

Ethical approval

The study was approved by the Institutional Review Board of Bestian Seoul Hospital (IRB No. 2019-02001) and performed in accordance with the principles of the Declaration of Helsinki. Written informed consent was obtained.

\section{Patient consent}

The patient provided written informed consent for the publication and the use of her images.

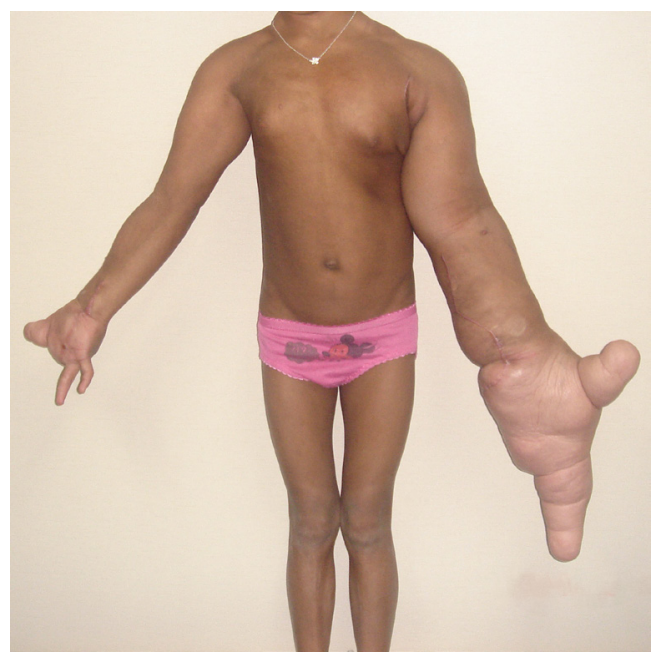

Fig. 4.

This picture shows the patient's early appearance after surgery.

\section{ORCID}

SukJoon Oh https://orcid.org/0000-0001-7793-

6198

\section{References}

1. Prasetyono TO, Hanafi E, Astriana W. A review of macrodystrophia lipomatosa: revisitation. Arch Plast Surg 2015;42:391-406.

2. van der Meer S, Nicolai JP, Schut SM, et al. Bilateral macrodystrophia lipomatosa of the upper extremities with syndactyly and multiple lipomas. J Plast Surg Hand Surg 2011;45:303-6. 